\title{
MEMBANGUN KESADARAN PENTINGNYA NILAI \\ KESELAMATAN PASIEN UNTUK MENCIPTAKAN BUDAYA KESELAMATAN PASIEN
}

\author{
ANGEL OKTAVIA PURBA / 181101099
}

angeloktavia013@gmail.com

\begin{abstract}
ABSTRAK
Keselamatan pasien adalah prinsip dasar dalam pelayanan kesehatan. Menurut Depkes RI (2008) Keselamatan pasien (patient safety) rumah sakit adalah suatu sistem dimana rumah sakit membuat asuhan pasien lebih aman. Tujuan dari pelaksanaan keselamatan pasien di rumah sakit adalah untuk melindungi pasien dari kejadian yang tidak diharapkan. Tujuan dari penulisan ini adalah untuk mengetahui apa itu Keselamatan pasien, Tujuan keselamatan pasien, dan bagaimana langkah-langah memabangun nilai kesadaran pentingnya keselamatan pasien. Metode penulisan ini adalah Literature Riview, dimana ini menganalisis artikel yang relevan dan berfokus pada tema Pembangun kesadaran pentingnya keselamatan pasien.
\end{abstract}

Kata Kunci : Keselamatan Pasien, pentingnya keselamatan pasien, Membangun kesadaran parawat.

\section{ABSTRACT}

Patient safety is a basic principle in health care. According to the Indonesian Ministry of Health (2008) Hospital patient safety is a system in which hospitals make patient care safer. The purpose of implementing patient safety in hospitals is to protect patients from unexpected events. The purpose of this paper is to find out what patient safety is, patient safety goals, and how to develop awareness of the importance of patient safety. This writing method is Riview Literature, where it analyzes relevant articles and focuses on PM themes to build awareness of the importance of patient safety.

\section{LATAR BELAKANG}

Keselamatan pasien menjadi prioritas utama dalam rumah sakit. Hal ini sangat erat kaitannya baik dengan citra rumah sakit maupun keamanan pasien. Tujuan dari pelaksanaan keselamatan pasien di rumah sakit adalah untuk melindungi pasien dari kejadian yang tidak diharapkan. Risiko kejadian ini berasal dari proses pelayanan yang dilakukan oleh tenaga kesehatan melalui programprogram yang telah ditetapkan oleh rumah sakit (Depkes RI, 2008). Keselamatan pasien adalah prinsip dasar 
dalam pelayanan kesehatan. Menurut Depkes RI (2008) Keselamatan pasien (patient safety) rumah sakit adalah suatu sistem dimana rumah sakit membuat asuhan pasien lebih aman. Sistem tersebut meliputi: assessmen risiko, identifikasi dan pengelolaan hal yang berhubungan dengan risiko pasien, pelaporan dan analisis insiden, kemampuan belajar dari insiden dan tindaklanjutnya serta implementasi solusi untuk meminimalkan timbulnya risiko. Sistem tersebut diharapkan dapat mencegah terjadinya cedera yang disebabkan oleh kesalahan akibat melaksanakan suatu tindakan atau tidak melakukan tindakan yang seharusnya dilakukan. Salah satu tujuan keselamatan pasien yaitu menurunnya KTD yang merupakan bagian dari insiden keselamatan pasien. Untuk mencapai tujuan tersebut, maka disusunlah Sasaran Keselamatan pasien yang bertujuan mendorong perbaikan spesifik dalam keselamatan pasien. Sasaran menyoroti bagian-bagian yang bermasalah dalam pelayanan kesehatan dan menjelaskan bukti serta solusi dari konsensus berbasis bukti dan keahlian atas permasalahan yang ada.

\section{TUJUAN}

Tujuan dari penulisan ini adalah untuk mengetahui apa itu Keselamatan pasien, Tujuan keselamatan pasien, dan bagaimana langkah-langah membangun nilai kesadaran pentingnya keselamatan pasien.

\section{METODE}

Metode penulisan ini adalah Literature Riview, dimana ini menganalisis artikel yang relevan dan berfokus pada tema PMembangun kesadaran pentingnya keselamatan pasien. Adapun artikel yang digunakan dalam literature ini menggunakan sumber dari buku teks, jurnal dengan memasukan kata kunci membangun kesadaran pentingnya keselamatan pasien . Adapun jurnal yang saya yang digunakan merupakan jurnal yang diiterbitkan pada 10 tahun terakhir.

\section{HASIL}

Berdasarkan pencarian literature didapatkan pengertian keselamatan pasien, tujuan keselamatan pasien dan bagaimana membangun kesadaran pentingnya nilai keselamatan pasien. 


\section{PEMBAHASAN}

Keselamatan pasien adalah prinsip dasar dalam pelayanan kesehatan. Menurut Depkes RI (2008) Keselamatan pasien (patient safety) rumah sakit adalah suatu sistem dimana rumah sakit membuat asuhan pasien lebih aman. Keselamatan Pasien (Patient Safety) merupakan sesuatu yang jauh lebih penting dari pada sekedar efisiensi pelayanan. Dan salah satu tujuan pentingnya adalah mencegah dan mengurangi terjadinya insiden keselamatan pasien. Perilaku perawat yang tidak menjaga keselamatan akan berkontribusi terhadap insiden keselamatan pasien. Perawat yang tidak memilki kesadaran terhadap situasi yang cepat memburuk gagal mengenali apa yang terjadi dan mengabaikan informasi klinis penting yang terjadi pada pasien dapat mengancam keselamatan pasien (Reid,2012). Perilaku perawat dengan kemampuan perawat sangat berperan penting dalam pelaksanaan keselamatan pasien. Perilaku yang tidak aman, lupa, kurangnya perhatian/motivasi, kecerobohan, tidak teliti dan kemampuan yang tidak memperdulikan dan menjaga keselamatan pasien berisiko untuk terjadinya kesalahan dan akan mengakibatkan cedera pada pasien, berupa Near Miss (Kejadian Nyaris Cedera) atau Adverse Event (Kejadian Tidak Diharapkan/KTD) selanjutnya pengurangan kesalahan dapat dicapai dengan memodifikasi perilaku. Perawat harus melibatkan kognitif, afektif dan tindakan yang mengutamakan keselamatan pasien. Keselamatan pasien merupakan tanggung jawab semua pihak yang berkaitan dengan pemberi pelayanan kesehatan. Perawat juga bertanggung jawab dalam meningkatkan keselamatan pasien namun masih banyak ditemukan perawat belum sepenuhnya sadar tentang betapa peningnya keselamatan pasien tersebut. Untuk itu perawat perlu membangun kesadaran dalam meningkatkan keselamatan pasien di Rumah Sakit.

Salah satu hal yang harus dilakukan adalah menerapkan langkahlangkah keselamatan pasien. Langkahlangkah keselamatan pasien diuraikan menjadi: 1. Membangun kesadaran akan nilai keselamatan pasien.

2. Pimpin dan dukung staf ;. 3. Integrasikan aktivitas pengelolaan resiko Mengintegrasikan pengelolaan resiko dilakukan untuk memberikan pembelajaran bagi setiap unit yang berada di rumah sakit ;. 4. Kembangkan sistem pelaporan Hal yang sangat penting dalam menjalankan langkah ini adalah sifat terbuka;. 
5. Belajar dan berbagi pengalaman tentang keselamatan pasien;.

6. Cegah cedera melalui implementasi sistem keselamatan pasien;.

7. Libatkan dan berkomunikasi dengan pasien.

\section{KESIMPULAN}

Keselamatan pasien adalah prinsip dasar dalam pelayanan kesehatan. Menurut Depkes RI (2008) Keselamatan pasien (patient safety) rumah sakit adalah suatu sistem dimana rumah sakit membuat asuhan pasien lebih aman. Keselamatan Pasien (Patient Safety) merupakan sesuatu yang jauh lebih penting dari pada sekedar efisiensi pelayanan. Perawat juga bertanggung jawab dalam meningkatkan keselamatan pasien namun masih banyak ditemukan perawat belum sepenuhnya sadar tentang betapa peningnya keselamatan pasien tersebut. Untuk itu perawat perlu membangun kesadaran dalam meningkatkan keselamatan pasien di Rumah Sakit.

\section{SARAN}

Keselamatan pasien menjadi prioritas di dalam memberikan pelayanan di Rumah Sakit. Untuk itu petugas kesehatan termasuk perawat harus mampu memotivasi dirinya sendiri untuk membangun kesadaran pentingnya nilai keselamatan pasien di Rumah Sakit.

\section{DAFTAR PUSTAKA}

Basabih, Masyitoh. (2017).Perlukah Keselamatan Pasien Menjadi Indikator Kinerja RS. BLU ?. Jurnal Administrasi Rumah Sakit Indonesia. 3(2): 150-157.

Darliana, D. (2016). Hubungan Pengetahuan Perawat dengan Upaya Penerapan Patient Safety di Ruang Rawat Inap RSUD Dr. Zainoel Abidin Banda Aceh. Idea Nursing Journal. 7(1): 62-63.

Departemen Kesehatan RI. (2008). Upaya Peningkatan Mutu Pelayanan Rumah Sakit. Jakarta: Depkes RI.

Efendi, Ferry, dan Makhfudli. (2009). Keperawatan Kesehatan Komunitas :Teori dan Praktik Dalam Keperawatan. Jakarta : Salemba Medika.

Firawati. (2012). Pelaksanaan Program Keselamatan Pasien di RSUD Solok. Jurnal Kesehatan Masyarakat. 6(2): 7477.

Ismainar, Hetty. (2015). Keselmatan Pasien di Rumah Sakit. Yogyakarta: Deepublish.

Kemenkes RI. (2011). Peraturan Menteri Kesehatan Republik Indonesia Nomor1691/MENKES/PER/VIII/2011 tentang Keselamatan Pasien Rumah Sakit. Jakarta: Depkes RI. 
Nugroho, Sri H.P., Sujianto,U. (2014). Supervisi Kepala Ruang Model Proctor Untuk Meningkatkan Pelaksanaan Keselamatan Pasien. Jurnal Keperawatan Indonesia. 20(1): 56-64.

Permenkes RI. (2011). Peraturan Menteri Kesehatan Republik Indonesia Nomor 1691/Menkes/Per/VIII/2011 Tentang Keselamatan Pasien Rumah Sakit. Jakarta: Depkes RI.

Permenkes RI. (2017). Peraturan

Menteri Kesehatan Republik Indonesia Nomor 34 Tahun 2017 Tentang Akreditasi Rumah Sakit. Jakarta: Depkes RI.

R.H Simamora. (2019). Buku Ajar Pelaksanaan Identifikasi Pasien : Uwais Inspirasi Indonesia.

R.H. Simamora. (2019). Documentation Of Patient Identification Into The Electronic System to Improve the Quality of Nursing Service. Internasional Journal of Sciiebtific \& Technology Research, Vol 08(09),18841886.
R.H. Simamora. (2019). The Influence Of Training Handover Based SBAR Communication For Improving Patients Safety. Indian Journal Of Public Health Research \& Development, Vol 09, $1280-1285$.

Tutiany, Lindawati, Krisanti P. (2017). Bahan Ajar Keperawatan: Manajemen Keselamatan Pasien. Jakarta: Kemenkes RI.

Utarini, A. \& Djasri, H. (2012). Keselamatan Pasien dan Mutu Pelayanan Kesehatan. Jurnal Manajemen Pelayanan Kesehatan. 159160.

Yulidar, E. \& Nasution, A. (2019). Analisi Faktor-Faktor yang Mempengaruhi Perilaku Perawat Dalam Rangka Penerapan Patient Safety di Rawat Inap RS. Royal Prima Jambi Tahun 2018. Scientia Journal. 8(1): 370-371. 